
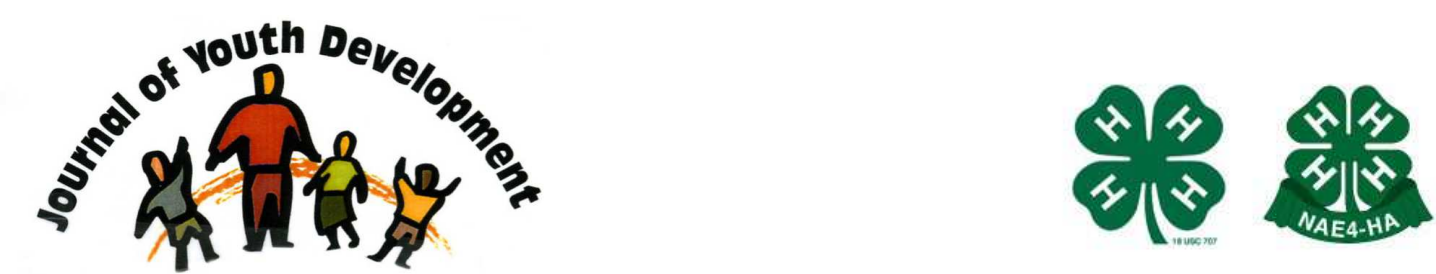

Bridging Research \& Practice

\title{
Cultivating Compassion and Youth Action Around the Globe: A Preliminary Report on Jane Goodall's Roots \& Shoots Program
}

\author{
Laura R. Johnson \\ University of Mississippi \\ ljohnson@olemiss.edu \\ Julie S. Johnson-Pynn \\ Berry College \\ Rome, GA \\ jpynn@berry.edu
}




\title{
JOURNAL OF YOUTH DEVELOPMENT \\ bridging research and practice

\section{Cultivating Compassion and Youth Action Around the Globe: A Preliminary Report on Jane Goodall's Roots \& Shoots Program}

\author{
Laura R. Johnson \\ University of Mississippi \\ Julie S. Johnson-Pynn \\ Berry College
}

\begin{abstract}
This paper describes a unique service-learning based environmental and humanitarian program for youth, The Jane Goodall Institute's Roots and Shoots program (R\&S). R\&S aims to foster learning, personal growth and civic engagement among youth members through service activities and environmental education. Despite its promise as a youth development program and its rapid expansion into 100 countries, little is known about R\&S's impact on youth development. In this study, we explore R\&S programs in China and Tanzania, two countries that are maximally different from the U.S. in important cultural and contextual factors. Through qualitative and quantitative methods we describe the programs, their practices, and perceptions of their impact on youths' personal and social development (cognitive and social competence, leadership, self-efficacy, citizenship and social responsibility). Additionally, we highlight the importance of sociocultural and ecological factors when developing and evaluating youth programs.
\end{abstract}

\section{Introduction}

This paper describes a unique approach to youth development, the Jane Goodall Institute's Roots and Shoots program, and reports on our initial fieldwork investigating program efforts to promote positive youth development across different cultural and ecological contexts. R\&S is a 
service learning-based environmental and humanitarian program founded in 1991 by Dr. Jane Goodall, the famous primatologist, environmentalist, humanitarian and U.N. Messenger for Peace.

After studying chimpanzees in the Gombe forest of Tanzania for thirty years, Dr. Goodall realized that protecting the Gombe chimps would require a grassroots, community effort involving youth participation in sustainable development activities. R\&S thus began with a small group of Tanzanian youth learning about the richness of their own environment and creating solutions to environmental threats and humanitarian concerns in their own community. R\&S promotes a service-based approach to environmental education, advocating hands-on experiences, community activism and global connections to promote learning, personal growth and resilience. Since its inception, R\&S has grown dramatically with approximately 8,000 groups in over 100 countries and in every state in the Unites States (The Jane Goodall Institute, 2007).

\section{Program Characteristics}

\section{Mission and Goals}

The R\&S mission is "to foster respect and compassion for all things, to promote understanding of all cultures and beliefs, and to inspire each individual to take action to make the world a better place for humans, animals and the environment" (The Jane Goodall Institute, 2005). R\&S aims to educate youth about their environments and to propel them to create sustainable solutions to environmental and humanitarian concerns. It also seeks to encourage understanding and cooperation among different individuals, cultures, ethnic groups and religions, and to enhance youth's self-respect, confidence and hope for the future (The Jane Goodall Institute, 2005).

R\&S groups, consisting of youth members and an adult facilitator, plan and carry out projects to benefit animals, people and the environment. Ideally, groups address each area every year, with one or more projects being ongoing initiatives. Projects are conceived of and carried out largely by youth members, although groups do have adult facilitators who take on different roles depending on the members' ages.

\section{Learning Model}

R\&S's model is based on service-learning pedagogy, which has its theoretical roots in John Dewey's philosophy of experiential, hands-on education and reflection (Dewey, 1938; Giles, \& Eyler, 1994; Waterman, 1997; Zeldin, \& Tardov, 1997). R\&S has a simple learning model consisting of three reciprocally influential components of knowledge, action, and compassion (see Figure 1.) 


\section{Figure 1}

R\&S Learning Model showing the reciprocal influence of knowledge, action and compassion

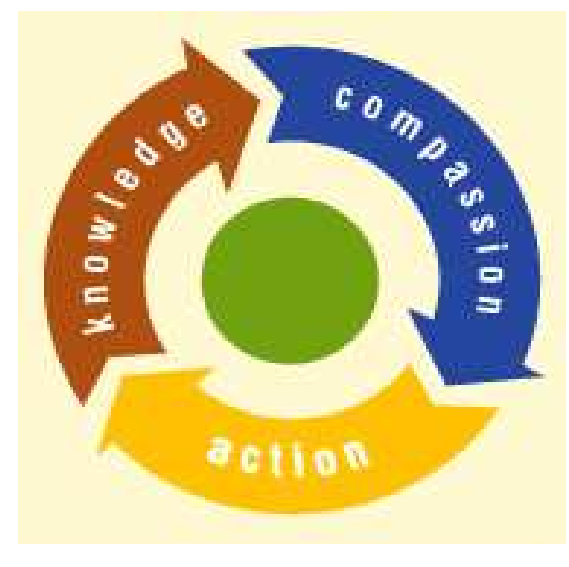

* Figure printed with permission from the Jane Goodall Institute.

Learning about the complexities of environmental problems (Knowledge) is considered crucial to developing feasible and sustainable solutions and for establishing credibility within the community. In fact, R\&S encourages youth to conduct a community needs assessment to help them identify locally relevant projects to benefit animals, the environment, and people. A deep understanding of local environmental issues is facilitated by community service work (Action), and reflective activities, such as discussions and project evaluations. These service experiences also build community connections for youth and foster the development of caring and compassion (Compassion) that further inspire service and community activism.

In addition to the learning model, $R \& S$ has a number of core features that enhance its relevance and applicability worldwide.

\section{Youth as Resources}

R\&S is based on Jane Goodall's belief that when youth are informed and empowered they will become leaders for environmental and human rights. R\&S's slogan "every individual matters, every individual has a role to play, every individual can make a difference" and, more recently, "The power of youth is global," (JGI, 2003) affirms R\&S view of youth as problem solvers and leaders in environmental sustainability. The program promotes maximal youth empowerment and leadership in selecting, carrying out and evaluating projects. A youth leadership council, youth summits and leadership trainings are additional avenues used to maximize youth leadership capacities. R\&S is thus consistent with movement toward positive approaches in psychology, and in particular toward youth programs focused on youth civic engagement (Larson, 2000; Lerner, Brentano, Dowling, \& Anderson, 2002; Lerner, Fisher, \& Weinberg, 2000; Kaufman, \& Rizzini, 2002; Rich, 2003). 


\section{Holistic, Ecological Approach}

R\&S broadly conceptualizes environmental issues to include, not only the natural environment and animals, but the human community as well. This holistic approach to youth programming acknowledges the importance of various ecological contexts, such as home, school and community in youth development (Blythe, \& Leffert, 1995; Bronfenbrenner, 1989; Seidman, \& Tseng, 2005). Moreover, increasing attention is being given to the importance of environmental concerns worldwide. The United Nations has declared 2005-2014 as the "Decade of Education for Environmental Sustainability" and the American Psychological Association's executive director for education has urged psychologists to take an interest in promoting environmental sustainability (Belar, 2007).

\section{Local and Global Connections}

Not only does the R\&S approach emphasize the interconnectedness of environmental and humanitarian concerns, but also the need for collaboration and connection among individuals and organizations. R\&S encourages and helps groups create global and local partnerships between groups, regions, schools, businesses and institutions. Groups from different countries can also be linked together for cross-cultural exchange through the Partnerships in Understanding program.

\section{Cultural Competence}

With the increased cultural diversity in the United States and the growing multicultural nature of society worldwide, more and more attention to cultural competence in youth programming is needed. Generally speaking, the R\&S model is simple enough and flexible enough to be adapted for cultural appropriateness in any setting and context. Projects arise from community and youth concerns, and the culture of the different programs will evolve from their local context in a way that is responsive to community issues. In this way, chances that group practices and program foci will be socio-culturally and environmentally relevant are enhanced.

Additionally, R\&S views culture as a resource. Cultural strengths, practices, and values can be built into programs; cultural diversity is celebrated and valued; and intercultural communication is encouraged and facilitated. This may enhance a positive ethnic identity in youth (Phinney, 1990). Moreover, the R\&S focus on positive youth development and youth community service has broad cross-cultural and multicultural appeal. Similar to cultural competence initiatives in health and mental health (American Psychological Association, 2003; Sue, \& Sue, 2003), R\&S is built on a foundation of social justice values, such as equality, openness to others, selfdetermination, human rights, and social and environmental justice.

\section{Flexibility}

Existing in 100 countries and across many settings and ages, R\&S groups are quite variable. Many groups, including the ones studied here, are located in schools, while others are based in communities, within other organizations or institutions (e.g. refugee camps, prisons systems), or even within families. Sizes range from very large (e.g. entire schools) to very small with just a handful of individuals. The learning model and its charge to take action are simple and flexible. Where curriculum materials and project ideas are made available, R\&S encourages flexibility and adaptability based on developmental, cultural and other contextual considerations. 


\section{Rationale}

\section{Present Study}

Service learning programs, such as R\&S, are gaining increased attention from educators, psychologists and youth program planners. This interest parallels the growing global interest in preventive mental health, resilience and positive youth development (Bolt, 2004; Larson, 2000; Lerner, et al., 2000). Moreover, strengths based approaches that focus on building protective factors; enhancing individual and community assets and promoting youth empowerment are recommended as culturally responsive practices (Sue, \& Sue, 2003). R\&S's broad environmental focus, basic human rights framework, and emphasis on youth service and civic engagement also have broad cross-cultural appeal and global applicability (Chawla, 2002).

Thus far, studies of service-based programs have shown positive program outcomes for youth across a number of factors that promote resilience and prepare youth to take active roles in bettering their communities. Positive program effects have been demonstrated in the areas of problem-solving ability (e.g., Eyler, Root, \& Giles, 1998), moral reasoning (Conrad, \& Hedin, 1982), and overall academic performance (Markus, Howard, \& King, 1993). Gains have been reported in empathic understanding (Yogev \& Ronen, 1982) and positive attitudes toward adults (Conrad, \& Hedin, 1982) and diverse groups in society (Myers-Lipton, 1996). Additionally, service learning has been demonstrated to facilitate the development of protective factors, such as self esteem and self efficacy, qualities which may help insulate children from daily stress and social/emotional problems (Clary, Snyder, Ridge, Copeland, Stukas, Haugen, \& Miene, 1998; Niiya, Crocker, Bartmess, 2004; Speck 2001). While these benefits have been well documented in American and European settings, programs also show promise for youth in developing and non-Western countries.

Despite international rhetoric on youth collective action, cross-cultural research is lacking on youth programs and how forms of participatory practice contribute to psychosocial development and civic engagement (Seidman, \& Tseng, 2005). Researchers and practitioners argue that efforts to promote and evaluate youth development programs must be ecologically grounded in the cultural, sociopolitical and geographic contexts that influence "real world" programs (Jensen, Hoagwood, \& Trickett, 1999). With the majority of the world's youth living in nonWestern countries, it is imperative that efforts to examine and implement successful programs be expanded to consider youth from diverse cultural and ecological backgrounds. This study is part of a larger effort to examine and enhance R\&S program viability and outcomes across a range of cultural and ecological contexts.

In this paper, we explore R\&S programs in two countries that are maximally different from the U.S. in important cultural and contextual factors. Through qualitative and quantitative methods (interviews, self-report surveys, program records, observations and participatory experiences) we describe R\&S programs in China and Tanzania and explore perceptions of program impact on members across a number of personal development domains (cognitive and social competence, leadership, self-efficacy, citizenship and social responsibility). Additionally, we highlight the importance of contextual factors by comparing and contrasting Chinese and East African R\&S groups. 


\section{Methods}

Qualitative and quantitative methods were used (interviews, surveys, program records, observations and participatory experiences) to explore perceptions of program impact on youth members. Data were collected on-site with R\&S groups in Tanzania and China. Multiple sources of information were used to provide a rich picture of R\&S groups.

\section{Interviews}

Twelve focus groups (averaging 10 members) and twenty key informant interviews were held with Chinese and Tanzanian R\&S youth members, volunteer teachers, and program coordinators. A semi-structured, open-ended interview was developed to elicit information about program characteristics and activities, perceptions of impact on members' personal and social development, and program successes and challenges. Interviews were conducted in English, with interpretation in Mandarin and Swahili as indicated. Interviews were taped, transcribed and content analyzed. Units of meaning were identified and coded to identify central themes. Next, data were grouped into categories and labeled to reflect a priori categories (i.e. major domain constructs of service learning and youth development) and new themes that emerged from the data (e.g. cultural and contextual information) (Miles, \& Huberman, 1994).

\section{Surveys}

Self-report surveys designed to tap service learning and youth development constructs were administered to English speaking Tanzanian $(\mathrm{N}=105)$ and Chinese $(\mathrm{N}=40)$ youth members. Program activities and meetings were observed and group records and activity reports were reviewed. Detailed contextual information on each country, study methodologies, and results are reported elsewhere (for China; Johnson, et al., 2007; for Tanzania; Johnson-Pynn, \& Johnson, 2005a; 2005b).

\section{Results}

\section{Activities}

Based on interview data and group records, R\&S groups in China and Tanzania reported similar activities, program practices and positive gains by youth. Activities of all groups expressed care and concern for the natural environment, the human community, and animal welfare, with the majority of projects in both countries focused on the natural environment, followed by the human community and animals.

Despite comparable activities, practices, and outcomes, national differences emerged in the amount of emphasis placed on various program aspects and in the contextual factors impacting programs (see Table 3). For example, among natural environment activities, groups in China reported recycling efforts, whereas Tanzanian youth reported reusing products and reducing waste (e.g. plastic bags). Other differences in activities included a Tanzanian emphasis on sustainable development and income generation and a Chinese emphasis on conducting research and evaluation studies.

\section{Perceived Program Impact on Youth}

Results from self-report surveys and focus group interviews suggest that R\&S is increasing environmental knowledge, raising community awareness, and fostering personal and social 
development. Across groups in both countries, gains of a medium to large program impact were reported in cognitive competencies (planning, organizing, critical thinking), social competencies (cooperation, negotiation, leadership), self-efficacy, sense of social responsibility and commitment to environmental and humanitarian values and social action. Membership also fostered social connections and positive feelings at community, national and global levels. Gains in leadership skills and in global environmental knowledge were the smallest reported for both groups.

\section{Similarities}

Interestingly, youth in both countries agreed in their ranking of program outcomes, with both groups ranking a belief that they will continue and a sense of duty to improve the world among the highest areas of perceived program impact. (see Table 1.)

Table 1

Three Highest Ranking Areas of Program Impact

\begin{tabular}{|l|l|l|l|}
\hline Mean (SD) & CHINA & TANZANIA & Mean (SD) \\
\hline $2.51(.56)$ & $\begin{array}{l}\text { Continue with efforts } \\
2.51(.60)\end{array}$ & Duty to improve & \\
\hline $2.49(.56)$ & Desire for fairness and justice & Duty to improve & $2.89(.34)$ \\
\hline $2.46(.60)$ & Get along w/ others & Success in school & $2.63(.58)$ \\
\hline
\end{tabular}

Youth in both counties also agreed in their lowest ranked items, with global environmental knowledge ranking lower than all other program areas, including local environmental knowledge (see Table 2). This is not surprising given the technological isolation of the Tanzanian groups and the historical sociocultural and economic isolation of China. Leadership was also ranked amongst both groups as an area of lesser gain. This indicates that leadership opportunities may not be available to all youth.

Table 2

Three Lowest Ranking Areas of Program Impact

\begin{tabular}{|l|l|l|l|}
\hline Mean (SD) & CHINA & TANZANIA & Mean (SD) \\
\hline $1.67(.70)$ & $\begin{array}{l}\text { Knowledge of global } \\
\text { environment }\end{array}$ & $\begin{array}{l}\text { Knowledge of global } \\
\text { environment }\end{array}$ & $1.95(.73)$ \\
\hline $1.97(.67)$ & Leading others & Leading others & $2.13(.56)$ \\
\hline $2.05(.79)$ & Decision making & $\begin{array}{l}\text { Knowledge of local } \\
\text { environment }\end{array}$ & $2.28(.60)$ \\
\hline
\end{tabular}

\section{Differences}

Despite some similarities, Chi square analyses between groups suggested differences in program impact in the areas of decision making $\left(X^{2}(2)=10.43, p<.05\right)$; school performance $\left(X^{2}(2)=17.64, p<.05\right)$; and belief about continuing $\left(X^{2}(2)=21.94, p<.05\right)$, with Chinese groups reporting reduced benefits compared to Tanzanian youth in each case. According to 
these results, Chinese youth are not reporting the same gains in academic performance as East African youth, with only $34.2 \%$ (versus $67.6 \%$ ) indicating that $R \& S$ resulted in large academic gains (see Figure 2). Additionally and possibly related to this, Chinese youth were less confident in their sustained efforts. This again may reflect contextual differences. With the intense pressure to succeed on school exams, R\&S may be seen as competing with time spent studying and could lead to attrition. On the other hand, R\&S experiences among Tanzanian youth may be seen as aiding academic and vocational potential.

Figure 2

\section{Program Influence on Academic Performance}

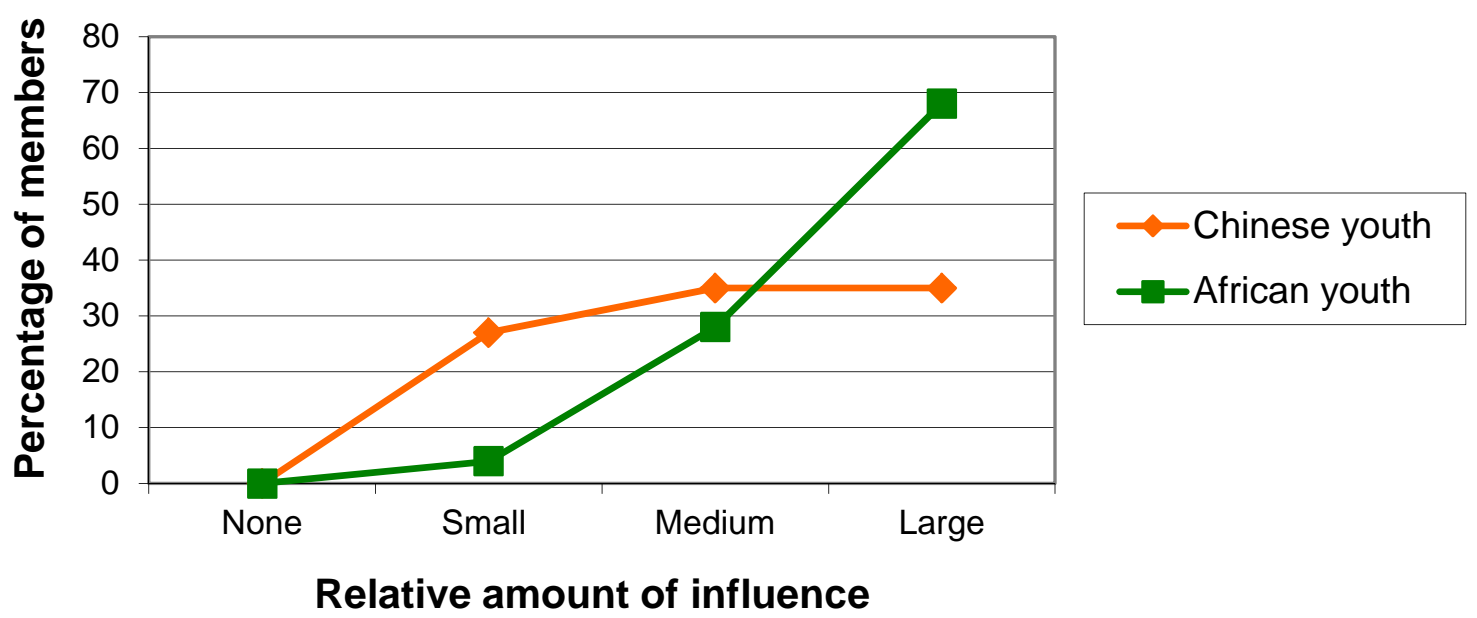

Figure 3

\section{Program Influence on Members' Desire to Continue Conservation Efforts}

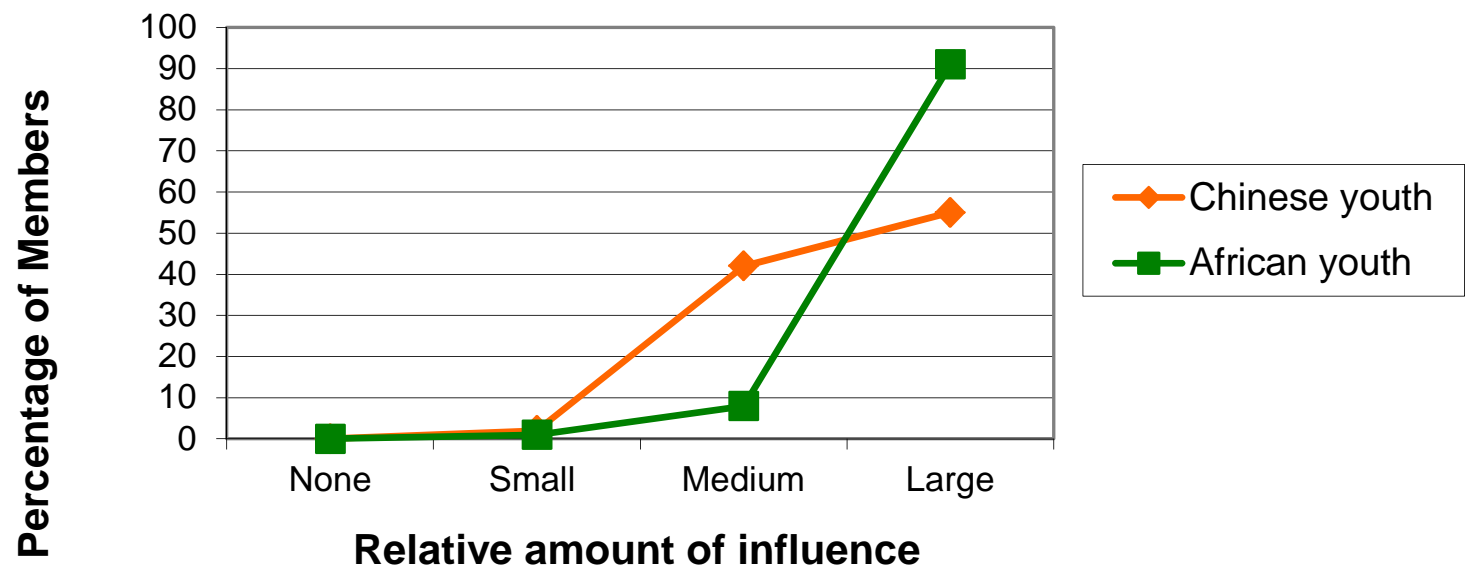




\section{Ecological Factors}

The impact of the different contexts on programs was evident to the researchers in both countries. In China, academic pressures, social isolation, economic changes, sociopolitical sensitivities and a new focus on individualism were recurrent themes (Johnson, et al, 2007) In Tanzania, poverty, developmental needs, and health care concerns were thematic (JohnsonPynn, \& Johnson, 2005a). Groups interviewed in Tanzania were more likely to be in rural settings, while those in China were more urban. Contextual factors influenced the activities, the program practices, and project barriers (see Table 3).

Table 3

Some Thematic Differences and Similarities between Groups

\begin{tabular}{|c|c|c|}
\hline CHINA & & TANZANIA \\
\hline $\begin{array}{l}\text { "Opening Up Policy" } \\
\text { (economic growth) } \\
\text { Environmental pollution and } \\
\text { unrest (74,000 protests in } \\
\text { 2004) } \\
\text { "One-Child Policy" \& urban } \\
\text { migration } \\
\text { Political history (Cultural } \\
\text { Revolution) and current } \\
\text { government control } \\
\text { Academic Pressure } \\
\text { Collectivist (vertical) cultural } \\
\text { values }\end{array}$ & \begin{tabular}{|l} 
CONTEXTUAL \\
INFLUENCES
\end{tabular} & $\begin{array}{l}\text { Poverty; Few resources } \\
\text { Lack of infrastructure; } \\
\text { Deforestation; Poaching } \\
\text { Sociocultural change \& urban } \\
\text { migration } \\
\text { Political issues-mass refugee influx } \\
\text { from Rwanda, Congo; prior involvement } \\
\text { in Uganda's civil war } \\
\text { History of experiential education } \\
\text { under Nyerere } \\
\text { Collectivist (horizontal) cultural } \\
\text { values }\end{array}$ \\
\hline $\begin{array}{l}\text { Environmental pollution } \\
\text { (recycling, water) } \\
\text { Research on effects of } \\
\text { industrialization } \\
\text { Care for sick children } \\
\text { Pet care }\end{array}$ & PROGRAM FOCI & $\begin{array}{l}\text { Natural resource management } \\
\text { (Agroforestry, ecotourism) } \\
\text { Income generation, practical skills } \\
\text { (tree nursery, beekeeping) } \\
\text { Malaria and AIDS awareness } \\
\text { Domestic animal care }\end{array}$ \\
\hline $\begin{array}{l}\text { Building academic capacity } \\
\text { (cognitive competencies) } \\
\text { Learning to work together } \\
\text { and get along } \\
\text { Self-confidence } \\
\text { Social relationships and } \\
\text { connections } \\
\text { Moral Character }\end{array}$ & $\begin{array}{l}\text { VALUED } \\
\text { OUTCOMES }\end{array}$ & $\begin{array}{l}\text { Building vocational \& life skills (e.g. } \\
\text { for subsistence farming or small } \\
\text { business management) } \\
\text { Community sensitization and } \\
\text { education } \\
\text { Leadership } \\
\text { Collective work }\end{array}$ \\
\hline $\begin{array}{l}\text { Intense academic pressure } \\
\text { reduces time for activities } \\
\text { Political climate requires } \\
\text { extreme sensitivity }\end{array}$ & CHALLENGES & $\begin{array}{l}\text { Poverty } \\
\text { Lack of resources to carry out } \\
\text { projects } \\
\text { Few teacher incentives } \\
\text { Poor communication due to lack of } \\
\text { infrastructure }\end{array}$ \\
\hline
\end{tabular}




\section{Successful Practices}

Despite the different contexts and unique challenges facing programs in China and Tanzania, $R \& S$ appears to be successful in both contexts. These results suggest that R\&S has the capacity to develop cognitive and social competencies, promote bonding, enhance self-efficacy, and facilitate environmental and pro-social action among Chinese and Tanzanian youth. The R\&S program as a whole, and groups discussed here, reported several program practices that will enhance their viability and impact on youth and their communities. These include:

- Sound, yet simple approach based on service learning, youth engagement and leadership (knowledge, action, compassion)

- Ample opportunities for discussion, analysis and reflection

- Cultural, developmental and contextual appropriateness

- Multiple collaborations, connections and social networks (group, community and global)

- Focus on the local and global environmental context in which youth live and develop (ecological framework)

These program aspects are desirable in service learning and positive youth development programs. With these core characteristics and the preliminary results reported here, R\&S has great relevance for today's youth and shows promise for promoting civic engagement (Lerner et al. 2000; Eyler, Root, \& Giles, 1998; Flanagan, \& Van Horn, 2001). However, these findings have several limitations, most notably social desirability. Although we sought different perspectives (youth members, teachers, coordinators) and different methods (focus group interviews, key informant interviews and self-report surveys), results may be inflated. Selection bias is another limitation, as groups were selected based on convenience and accessibility rather than randomly.

\section{Conclusion}

Though subject to limitations, these findings are consistent with those found in outcome studies of youth development and service learning programs in the U.S. (Catalano, et al., 2002; Eyler, et al., 1998). The success of R\&S in two countries with vastly different ecological systems speaks to the potential global applications of the program to promote compassion and youth action (Barber, Stoltz, \& Olsen, 2005; Limber, \& Kaufman, 2002). Moreover, with its focus on environmental sustainability, R\&S has much to offer the today's youth who undoubtedly face important environmental challenges to their livelihoods, now and in the future (Chalwa, 2002; Kaufman, \& Rizzini, 2002). This paper also draws attention to the importance of considering ecological factors, such as cultural values, economic restraints, sociopolitical climate, and environmental contingencies in implementing and evaluating youth programs.

\section{Future Directions}

At a programmatic level, R\&S is further developing its youth leadership initiative so that increasingly more youth have opportunities for leadership training and experiences. With this focus, R\&S aims to empower youths' voice and involvement not only in their communities, but and also within program. Currently, researchers are collaborating with the Jane Goodall Institute to conduct a more systematic and comprehensive evaluation of R\&S. Studies to assess youth outcomes and program practices are being conducted with a combined qualitative and 
quantitative approach. A survey tool assessing major areas of youth development and R\&S program practices is being tested for use in a pre-post design with control groups. A multinational "Global Youth Survey" is being conducted with standardized psychometric measures and groups in East Africa, including those located in a refugee camp, are being examined under a U.S. Fulbright grant. More program results will be forthcoming.

\section{More Information}

Educators, mental health providers, youth workers, environmentalists, parents or others interested in learning more about R\&S, or implementing it in their setting (e.g. school, community, youth group home) should visit the R\&S website at www.rootsandshoots.org. For more information about R\&S related research activities and opportunities please contact the fist author and/or visit www.olemiss.edu/research/cultural/rs.

\section{References}

American Psychological Association. (2003). Multicultural guidelines: Education training, research, practice and organizational change for psychologists. American Psychologist, 58, 377402.

Barber, B.K., Stolz, H.E., \& Olsen, J.A. (2005). Parental support, psychological control, and behavioral control: Assessing relevance across time, culture, and method. Monographs for the Society of Research in Child Development, 70(4), serial no. 282. Boston, MA: Blackwell Publishing.

Belar, C. (2007, March). Sustained efforts for sustainability. Monitor, 38 (2) retrieved March 7, 2007 from http://www.apa.org/monitor/mar07/soe.html.

Blythe, D.A., \& Leffert, N. (1995). Communities as contexts for adolescent development: An empirical analysis. Journal of Adolescent Research, 10(1), 64-87.

Bolt, M. (2004). Pursing human strengths: A positive psychology guide. NY: Worth Publishers.

Bronfenbrenner, U. (1989). Ecological systems theory. In R. Vasta (Ed.). Annuals of child development, 6 (pp. 187-251). Greenwich, CT: JAI.

Catalano, R.F., Berglund, M.L., Ryan, J.A.M., Lonczak, H.S., \& Hawkins, J.D. (2002). Positive youth development in the United States: Research findings on evaluations of positive youth development programs. Prevention \& Treatment, 5(15), 1-111. Retrieved September 12, 2005, from http://a:/pre0050015a.htm.

Chawla, L. (2002). The effects of political and economic transformations on children: The environment (pp. 91-98). In N.H. Kaufman \& I. Rizzini (Eds.), Globalization and children: Exploring potentials for enhancing opportunities in the live of children and youth. NY: Kluwer Academic/ Plenum Publishers. 
Clary, E.G., Snyder, M., Ridge, R.D., Copeland, J., Stukas, A.A., Haugen, J., et al. (1998). Understanding and assessing the motivations of volunteers: A functional approach. Journal of Personality and Social Psychology, 74, 1516-1530.

Conrad, D., \& Hedin, D. (1982). The impact of experiential education on adolescent development. Child and Youth Services, 4, 57-76.

Dewey, J. (1938). Experience and education. New York: Macmillan.

Eyler, J., Root, S., \& Giles, D.E., Jr. (1998). Service learning and the development of expert citizens: Service learning and cognitive science. In R.G. Bringle \& D.K. Duffy (Eds.), With service in mind: Concepts and models for service learning in psychology (pp. 85-100). Washington, DC: American Association of Higher Education.

Flanagan, C., \& Van Horn, B. (2001, Fall issue). Youth civic engagement: Membership and mattering in local communities. Focus, 1-11.

Giles, D.E., \& Eyler, J. (1994). The theoretical roots of service-learning in John Dewey: Toward a theory of service-learning. Michigan Journal of Community Service Learning, 1, 77-85.

Jensen, P.S., Hoagwood, K., \& Trickett, E. (1999). Ivory towers or earthen trenches? Community collaborations to foster real-world research. Applied Developmental Science, 3(4), 206-212.

Johnson, L.R., Johnson-Pynn, J.S., \& Pynn, T. (2007). Youth civic engagement in China: Results from a program promoting environmental activism. Journal of Adolescent Research, 22(4), 355386.

Johnson-Pynn, J., \& Johnson, L. $\left(2005^{\mathrm{a}}\right)$. Successes and challenges in East African conservation education. The Journal of Environmental Education, 36, 25-40.

Johnson-Pynn, J.S., \& Johnson, L. $\left(2005^{\mathrm{b}}\right)$. The Jane Goodall Institute's Roots \& Shoots program: Bettering the lives of East African youth and their ecology. Journal of Ethics in Leadership, 1, 17-31.

Kaufman, N.H., \& Rizzini, I. (Eds.). (2002). Globalization and children: Exploring potentials for enhancing opportunities in the live of children and youth. NY: Kluwer Academic/ Plenum Publishers.

Larson, R. (2000). Towards a psychology of positive youth development. American Psychologist, $55,170-183$.

Lerner, R.M., Brentano, C., Dowling, E.M., \& Anderson, P.M. (2002). Positive youth development: Thriving as the basis of personhood and civil society. In R.M. Lerner, M., C.S. Taylor, \& A. von Eye (Eds.) New directions for youth development. Pathways to positive development among diverse youth (pp. 11-34). San Francisco, CA: Jossey-Bass. 
Lerner, R.M., Fisher, C.B., \& Weinberg, R.A. (2000). Toward a science for and of the people: Promoting civil society through the application of developmental science. Child Development, 71, 11-20.

Limber, S.P., \& Kaufman, N.H.K. (2002). Civic participation in children and youth (pp. 81-90). In N.H. Kaufman, \& I. Rizzini (Eds.), Globalization and children: Exploring potentials for enhancing opportunities in the live of children and youth. NY: Kluwer Academic/ Plenum Publishers.

Markus, G.B., Howard, J., \& King, D.C. (1993). Integrating community service and classroom instruction enhances learning: Results from an experiment. Education Evaluation and Policy Analysis, 15, 410-419.

Miles, M.B., \& Huberman, A.M. (1994). Qualitative data analysis: An expanded sourcebook (2 ${ }^{\text {nd }}$ ed.). Thousand Oaks, CA: Sage.

Myers-Lipton, S.J. (1996). Effect of service learning on college students' attitudes toward international understanding. Journal of College Student Development, 37, 659-668.

Niiya, Y., Crocker, J., \& Bartmess, E.N. (2004). From vulnerability to resilience: Learning orientations buffer contingent self-esteem from failure. Psychological Science, 12, 801-805.

Phinney J.S. (1990). Ethnic Identity in Adolescents and Adults: Review of Research.

Psychological Bulletin, 108(3), 499-514.

Rich, G.J. (2003). The positive psychology of youth and adolescence. Journal of Youth and Adolescence, 32(1), 1-3.

Seidman, E., \& Tseng, V. (2005). Networks as an ingredient in youth mentoring and youth collective action programs. W.T. Grant Foundation Report and Research Guide.

Speck, B. (2001). Why service learning? New Directions for Higher Education, 114, 3-13.

Sue, D.W., \& Sue, D. (2003). Counseling the culturally diverse: Theory and practice ( ${ }^{\text {th }}$ ed.). New York, NY: John Wiley \& Sons Brofenbrenner, U. (1979). The ecology of human

development. Cambridge, MA: Harvard University Press.

The Jane Goodall Institute. (2007). What is Roots \& Shoots? Retrieved September 19, 2007 from http://www.rootandshoots.org/about-us/default.asp

The Jane Goodall Institute. (2005). Roots \& Shoots Coordinators Manual. The Jane Goodall Institute, Silver Spring, MD.

Waterman, A.S. (1997). Service learning: Applications from the research. London: Lawrence Erlbaum.

Yogev, A., \& Ronen, R. (1982). Cross-age tutoring: Effects on tutors' attributes. Journal of Educational Research, 75, 261-268. 
Zeldin, S., \& Tardov, S. (1997). Service learning as a vehicle for youth development. In J. Schine (Ed.), Service Learning: Ninety-sixth yearbook of the National Society for the Study of Education Chicago: University of Chicago Press.

(C) Copyright of Journal of Youth Development Bridging Research and Practice. Content may not be copied or emailed to multiple sites or posted to a listserv without copyright holder's express written permission. Contact Editor at: patricia.dawson@oregonstate.edu for details. However, users may print, download or email articles for individual use.

ISSN 2325-4009 (Print); ISSN 2325-4017 (Online) 
